\title{
SIBERIAN MOVEMENTS: HOW MONEY AND GOODS TRAVEL IN AND OUT OF NORTHWESTERN SAKHA ${ }^{1}$
}

\begin{abstract}
Aimar Ventsel
Abstract: In this article I want to discuss the notion of distance, movement and civilisation in Siberia. I focus on a particular type of people - traders - and their movements. The travels of traders in Siberia accompany the movement of goods and money and this movement is the main reason for their travels. In Siberia there exist many different perceptions of space and time. Incomers perceive the territory as a network linking the islands of civilisation. A Siberian native or sibiriak views his country as a large territory that is harsh and where movement needs a special investment in time and energy. I would like to show that traders as both incomers and sibiriaki define space, distances and time in a way that unites both discourses. The construction of space and distance is affected by economic, social and cultural factors that are rooted in the history of the region and a life style caused by the climate, economy and historical development of the region.
\end{abstract}

Key words: movement, post-Socialism, Sakha, trade

Perception of space and time is a popular topic in anthropology. However, there are many possible ways to discuss these issues. Relation to space (and in general approach to territory) and time (time spent by moving in the territory) is not objective but depends on social, economic, cultural and even historical settings and has been widely studied. In an Arctic context, the relevance of the means of transport, and the social and cultural setting is analysed in many works that discuss these topics foremost in a herders' and hunters' context (Pelto \& Müller-Wille 1987; Croll \& Parkin 1992; Ingold 2000; Vitebsky 2002). In this article I want to discuss the notion of distance, movement and the perception of civilisation in Siberia with a focus on a particular type of peopletraders - and their movement. The movement of traders in Siberia is accompanied with the movement of goods and money and this movement is the main reason for their travels. I chose the traders because they are a small but constantly mobile group whose income depends on their ability to cross vast distances. 
The collapse of the Soviet state caused several changes in everyday life such as the appearance of free trade, a process that is analysed by some scholars (Humphrey \& Hugh-Jones 1997; Mandel \& Humphrey 2002). The exchange of goods in a post-Soviet Russia is a complex sphere and only one segment can be discussed in this paper. The new breed of traders in English are often called "entrepreneurs", in Siberia they are commonly known as kommersanty ${ }^{2}$ which means "trader" although sometimes the term predprinimatel' (entrepreneur) is used. In my opinion there are two specific features about trade in Siberia: these are the high prominence of traveling and the practice of barter. Private traders operate through shops and markets but they also travel to remote villages (in order to sell their goods) and to big markets (in order to buy goods). Because distances are so vast in Siberia, traveling (i.e. spending a huge amount of time moving from one settlement to another) is an important part of trade. Private traders can spend more than a week on the road to reach a village by truck. As one driver working in this business said, he does five or six such long - approximately $2000 \mathrm{~km}$ - trips during the winter and earns money this way for the rest of the year. Siberian indigenous villages were always producers of meat, fish and furs, and in some regions other products like velvet reindeer antlers, mammoth tusks, pines, etc. These products are bartered with local or traveling traders for (usually big quantities of) food, clothes, equipment and even furniture (Ventsel 2005; Stammler \& Ventsel 2003; Stammler 2005; Ziker 2002). ${ }^{3}$

\section{INTRODUCTION OF THE FIELDWORK REGION}

My main fieldwork region was the Anabarskii district in the Republic of Sakha, the biggest subject of the Russian Federation that lies in the eastern part of the Russian Far East. The territory of the Republic of Sakha is more than 3 million square kilometres and is sparsely populated with less than a million inhabitants. That means that settlements are scattered over the land and hundreds of kilometres are between them. The Anabarskii district (located some $2000 \mathrm{~km}$ north from the republic's capital Yakutsk) in the most north western district of the republic, located on the coast of the Arctic Ocean is populated by 4000 people within 45,000 square kilometres. There is a winter road from Yakutsk to the district and also two airplane lines connecting the district centre village of Saskylakh with Yakutsk and the diamond mining town Mirnyi. Most of my fieldwork time in 2000-2001 was spent either in the village of Iuriung Khaia (150 km north from Saskylakh) or in the tundra with people from the village. The village of Iuriung Khaia is mainly inhabited by Turkic 
speaking Dolgan people, who are traditionally engaged in reindeer herding as well as wild reindeer or fur animal hunting. An additional activity for people in the whole district is also seasonal fishing and geese hunting.

Historically the district has always been a region that is crossed by two huge waves of reindeer migration - one from the Taimyr peninsula, another from the eastern tundra (Ventsel 2005: Chapter 1). Therefore the Anabarskii district was before the revolution a region where hunters and traders traveled from afar. According to historians, trade had impact on the economy of the region since the 18th century. Local hunters were engaged in sable and arctic fox hunting to satisfy the demand of traders who traveled north to barter flour, tea, alcohol, metal items, etc, for furs. In the Soviet era the district was an important meat producing region where collecting arctic fox furs was of secondary importance. The local indigenous population was sedentarised and collectivised into collective and state farms. They became wage labourers and were able to buy imported goods from local state shops that were centrally supplied by government organisations. My older informants told me that in Soviet era shops in the Anabarskii district there was a broader assortment than the shops in Yakutsk.

When I arrived in Iuriung Khaia in 2000, there existed only three privately run shops and no government owned one. All three shops were like tiny supermarkets, on sale in small rooms was literally everything the shop owners were able to provide - alcohol, clothes, video-recorders, food, sweets and more. Additionally, in the village lived some people who were introduced to me as "local kommersanty" i.e. traders who bought big quantities of fish or meat from local people and sold to them food items in big quantities. These traders were not only engaged in grocery and meat barter, people even ordered snowmobiles or furniture from them. A lot of this trade was a credit business meaning that local people bought huge amounts of food, equipment and ammunition at the beginning of the winter and paid for it at the end of the hunting season in spring.

\section{TWO EXAMPLES OF LOCAL TRADERS}

In a small building near to my host family's house was located one of the three shops. This was a two-room facility, the front room (ca. 12 sq metres) served as a shop and the back room as storage. In one corner was a small table with a few chairs around it, in another a counter and behind the counter was a shelf. The counter and shelf were overfilled with goods from children toys and sweets to canned food and sugar. The shop was owned by a woman in her fifties. 
I visited the shop often and became friends with the owner. I dropped in quite often not only to buy something but also to drink tea with her and have a quick chat. Sveta used to be a primary class teacher in the Iurung Khaia school and many of her customers were her former students. She had lived in the village for decades and was one of the five Russians in the settlement who did not leave after the state farm and Soviet economy collapse. As Sveta told me, she came to the village to spread "culture" and to "civilise" the local nomadic population (e.g., Anderson 2000b: 189-191). In the 1990s, when salaries arrived late or were not paid at all, she decided to quit her job at the school and opened the shop. According to her words, the local population has become now "non-cultured" (nekul'turnye) due to lack of work and alcohol abuse, "even women drink now" she said. Due to this, she was forced to sell more of her goods on credit that customers paid later when they had money. Over the years she became very successful. As Sveta told me, she insisted that her husband, who used to work as a mechanic at the local state farm, quit his job and came to help her with the shop because the income from the trade was bigger than a mechanic's salary. The goods in the shop were sold for cash, or bartered for meat and fish. As in all village shops in Russia, there was also an option to buy goods on credit, paying later when one had money. This possibility is often used by local indigenous women who needed sugar, tea or some other foodstuff in small quantities. Beside that, Sveta supplied many hunters and even hunting enterprises with goods like food, fishing nets, or other equipment. She ordered big quantities of goods from wholesale trading enterprises in Yakutsk and bartered these for fish and reindeer meat. For this purpose she had to organise container transportation to bring ordered consumables to the village or to ship meat and fish out of the district to the market.

During our conversations I heard that shop keeping in an Arctic village was not easy. First of all she had to pay the local police officer a few thousand roubles every month. The local constable in an Arctic village is like a Southern small town sheriff in a bad Hollywood movie. He is the law and any conflict with him can initiate harassment, tax and hygiene controls, arrestment of relatives for minor indiscretions etc. Apart of that, Sveta had to deal with the village administration which produced a lot of paperwork. Moreover, she had competitors in the village, other shops and illegal traders, who sold alcohol and food from their homes. Therefore Sveta had to be aware of the prices of other shopkeepers and illegal entrepreneurs, and also find her own niche in the local market. Sveta's niche was fashionable clothing and work clothes. Especially young girls were very interested in the latest fashion. As a rule, people from remote villages preferred to buy clothes in cities or asked city relatives to send them. On the other hand, travelling to Yakutsk and other 
Sakha towns was expensive, also sending parcels to Iuriung Khaia is complicated $^{4}$. This way fashion orientated people sometimes were forced to buy their clothes in district shops. In general, the clothes locally available were not cheap or good quality but very often it was the only option especially when the village was cut off from other settlements during winter or spring snow storms and one needed something for a birthday party next week. Last but not least, Sveta had to maintain good relations with the local people which means being very delicate when asking people to pay their debts. In a village where people are closely linked via kinship and friendship, maintaining good relations with everybody required serious political maneuvering. For that reason she had to write off minor debts when some families were unable to pay them on time. Nevertheless, I was struck when I found out that in general this small shop and the additional wholesale business brought in sufficient resources to build a house back home, in the Yaroslavl oblast in European Russia. As Sveta told me, her children were supervising the building process but the mother provided the money for the new house. However, she was not very sure about moving back to the European Russia, because she considered the village her home.

One day at the end of May in 2001, when visiting Sveta's shop I found her packing. She was pressing folded empty bags into a huge plastic bag closed with a zip. When I asked where is she planning to go she answered that she is flying to Nizhni Novgorod which is a city on the Volga, the northern part of European Russia, a city famous for its architecture. "There is a huge market where I buy clothes and bring them here to sell in the district," Sveta told me. She told me that she buys usually several huge travel bags full of new clothes. I admired her courage because she was travelling only with her twenty something year old son. According to Sveta, in the market she had to cope with local mafia and often bribe police or airport customs. "One good way of making money for them is they want to 'control' the content of my luggage before the plane. I have squeezed everything into the bags so that they are almost exploding. When they open the bags, I cannot pack everything in a hurry to catch the plane. So, I have to pay." The travel plan of Sveta and her son was to take a plane from the Anabarskii district to Yakutsk, then change to another plane and fly to Moscow where they wanted to take a train to Nizhni Novgorod. By coincidence we were in the same plane to Yakutsk and I wished her good luck when departing in Yakutsk airport. I have not seen her since but heard from friends that she still has the shop in Iuriung Khaia.

When I was in the district centre Saskylakh, I met another kommersant, Sergei. Together with his partner Pavel he runs a big scale supply business. Sergei lived in the Anabarskii district whereas Pavel was there only a few 
times a year. The rest of the year Pavel lived in Novosibirsk. The couple did not have a shop or even an office but they ran the business from a room in the local guesthouse where Sergei stayed when in the district. Sergei and Pavel supplied local hunting enterprises with food and equipment, also local people ordered snowmobiles, furniture and home electronics from them. Moreover, they ran a canteen in the village, were involved in the local food processing industry, invested some money into the local meat and fish smoking shop and were aiming to establish a small "milk industry" producing milk from imported milk powder. When Sergei had collected enough orders and people made their advance payments, Pavel bought the necessary goods and sent them to Saskylakh via cargo plane from Novosibirsk. Sergei traded with reindeer meat which he bought by the tons and transported to Yakutsk using cargo planes or trucks. Before the winter season, hunters and reindeer herders ordered big quantities of food and equipment paying in spring by foraged wild reindeer meat. The distances that goods had to pass were huge - from Saskylakh to Novosibirsk approximately $2600 \mathrm{~km}$ and $1600 \mathrm{~km}$ from Yakustk to Saskylakh as the bird flies. Involvement in such a large scale business meant a lot of networking for them both: they had to be on good terms with local people in the Anabarskii district to buy meat and secure orders, know people in the airport customs of both ends and so forth. This kind of trade requires great organisational competence to coordinate the movement of goods, obtain licenses for reindeer meat export, manipulate taxes, find workers, manage staff and so forth.

As we stayed often in the same hotel, I had plenty of chances to talk to Sergei. Sergei was registered in the district as a permanent inhabitant and literally "knew everybody". He arrived to the district already in the Soviet era and started his business activities in the 1990s. He saw some of his projects (wind mills, milk producing work shop) as part of the "civilisation" process with the aim to make life in the district more comfortable i.e. kul'turnyi. Sergei did not distance himself from the local people, as many other incomers in the village of Saskylakh did, and I noticed next to no prejudice in his attitude to the indigenous population. He was valued by the indigenous people as someone who was not afraid of hard work, and I saw him often in the polar night guiding the work of the wind mills. Local people described him often as "svoi" i.e. one of our kind, an appreciation that was not given to everyone. To some extent, Sergei was the embodiment of the sibiriak ethos, being reliable, fair in business, hard working and modest with the alcohol (e.g. Antipin 2011). 


\section{DISCUSSION}

Space is socially constructed and is filled with meanings and symbols (Foucault 1980; Harvey 1990; Lefebre 1991; Watts 1992; Weiner 2002). There are different strategies to mark the space: name it (Basso 1984), fill with tracks (de Certeau 1988) or concrete buildings and other human made constructions (Brandtstädter 2001). Foucault states that history is written in spaces, similar to Watts who adds that the space is defined by the existence of social control (Watts 1992; Foucault 1980) ${ }^{5}$. However, beside the inhabited space exists an empty space or "wilderness" that lacks all the previously mentioned markers. The anthropological literature shows that the border between meaningful and empty space is usually not fixed, in constant movement and needs to be redefined time by time (Gow 1996; Gray 2000).

Siberia is the region where the border between the "civilised" and "wild" space is especially obvious. "Administrative practices" have always played a great role in regional "imaginary geography" (Burbank \& Hagen 2007: 5) and fixed the border between the "civilised" and "wild" territory. Since the appearance of Russians in Siberia, the vast territory was divided between state controlled settlements and trading posts or "culturally significant places" (Kennedy 2002: 11) and the "wild" territory (see Kozlar 1955; Stephan 1994). Due to the industrial expansion and resource extraction since the 1950s settlements in Siberia are scattered over a vast territory leaving huge distances between the islands of "civilisation" (cf. Forsyth 1992; Mote 1998). The notion of the "civilised" space became especially strong with the building of new industrial towns all over Siberia, a process which became very rapid in the 1960s. One indigenous woman referred to the establishment of state farms as "the time when civilisation arrived to us" and one Russian bus driver told me proudly "When we arrived in this country, it was completely wild and empty". The industrial expansion had an ideological dimension, i.e. bringing "civilisation" to the "uncivilised" territory inhabited by "backwards" people (Forsyth 1992), an ideological dimension that found admiration and acceptance even among a few Western intellectuals (see Mowat 1970). In Siberia exists a popular perception of distinguishing "civilised" and "wild" space using the term "culture" (kul'tura in Russian) as also did Sveta and Sergei. David Anderson discusses the notion of "kul'tura" in Siberia and concludes that it should be translated as "civilisation" (1996: 104). Also in my observation "cultural" or "kul'turnye" are places that have running water, TV, electricity and in general "kul'tura" is associated with the arrival of "civil society in civic islands" (Anderson 1996: 111-112). Here Anderson refers to general opinion because in Siberia settlements are indeed 
interpreted by (especially incoming) people as islands of civilisation surrounded by wild nature and often wild people (cf. Anderson 2000b: 189-191). Here must be noted that this approach is not specific to the Russian or Soviet state and can be found throughout the history of the expansion of imperial states to territories that were seen as "empty" and "uncivilised" and are "open" to be filled with meanings through human activities (cf. Buchan \& Heath 2006; Ginsburg \& Meyers 2006; Wolf 1990; Bothe et al. 1993). Territories like Siberia were and still are viewed as a frontier that should be conquered and re-organised to link them with the already existing "cultured" world.

Historians show that already in Tsarist times European Russia was viewed as "proper Russia" (Sunderland 2007: 43). Therefore, from a Russian (and later Soviet) perspective Siberia was an uncivilised and empty territory on the outskirts of the country (okraina) that should be rationally mastered (osvoevat') and exploited (Kotkin \& Wolff 1995; Forsyth 1992; Mote 1998; Gerasimov et al. 2009). The reason for the interest in this "empty" territory were its rich mineral resources and therefore Siberia became a "resource frontier". This was the official Soviet political view accompanied with economic strategies (Slavin 1961), so was it also presented to foreigners (Mowat 1970). In the capitalist and socialist worlds, the frontier has always been associated with a "sense of contested space" and progress (Hine 1984; Brightman et al. 2010; Forsyth 1992). A frontier is an area where living conditions are rather harsh and people have to be tough. States use different strategies to control a frontier: they send in settlers, sedentarise indigenous nomads, establish military and trading outposts (Cañas Bottos 2008; Bassin 1991; Dedering 2002; Dick 1965; Kozlar 1955; Tilly 1975). Sometimes the process of annexation of frontiers can have backlashes: some scholars suggest that the policy of conquering and protecting the resource frontier is also one reason for the continuing economic problems for Russia as a state (Hill \& Gaddy 2003).

Social construction of a frontier is similar in all continents where "empty" territories were "heroically civilised". An archetype for the frontier in this sense is the Western frontier of the United States that has provided material for countless stereotypes, legends and cult heroes (Hine 1984). The typical American frontier inhabitant is a white man [because the frontier was a "world without women except Scarlet O'Hara" (Hine 1984: 287)] who rejects corrupt authority and lives in self-contested freedom. To stay alive, these men had to be innovative and use all possible means to literally survive. For example, historical research demonstrates that soldiers of US cavalry outposts had to make their own clothes, grow vegetables and hunt (Dick 1965). Therefore it is not surprising that in American popular thinking the heroic mastering of the frontier is often seen as the origin of national democracy (Billington 1956). At 
the same time the historical research shows that many of the stereotypes about the Western frontier are not true: for instance the US-frontier was mainly populated by men but not only by white men because quite a big number of soldiers, trappers and cowboys were blacks (Hine 1984: 223-225). Siberia as a frontier shares many similarities with other historical frontiers. Not only the American West was quite masculine, a similar lack of women also concerned men in Siberia or New France (Collins 2004). Ironically, Siberia, the American West and the Scandinavian North were seen as quasi-feminine "virgin" lands that became "domesticated" (i.e. gender wise neutral) not before women moved in and settled down with men (Argunova-Low 2006/2007; Kolodny 1984; LindeLaursen \& Nilsson 1995). In Siberia, this approach was also shared by the Tsarist government who had a policy of sending women forcibly to Siberia to create a socially "domesticated" environment for men (Gentes 2003). Nevertheless, Siberia is still seen as a masculine space, where "real men" do work in mines, hunting camps or at the steering wheel of a truck in a male space with very few women in sight, and the place in society has to be earned through heavy work and toil. The sex separation was also introduced into the lives of the indigenous population during the process of "bringing civilisation" (Vitebsky \& Wolfe 2001; Gracheva 1980). Like Sergei, one has to earn the respect and social position by demonstrating hardness through behaviour. This has also helped to establish a specific sibiriak ethos as morally and physically superior people to the "soft" inhabitants of European Russia (Antipin 2011). Siberian popular history is full of legends similar to the American frontier, when tough men have established villages, roads or mines or explored the land in order to map it and "conquer" it (Obrutšev [Obruchev] 1957). Typical to the colonialist perception of the frontier is that in all cases popular imagination ignores the fact that territories of the frontier were and are home to numerous indigenous people who have lived there for generations before "civilisation" was brought to them (Brightman et al. 2006/2007).

It seems that the main difference between the American West and Siberia as frontier areas is that Siberia is still an unfinished project. When according to public understanding, the American frontier was closed after the Wounded Knee massacre (Wilkie 2010: 49) then Siberia is still a territory that is in a state of being conquered. Moreover, the "civilized society" at the "edges of the polity" in Siberia has demonstrated its fragility (Brightman et al. 2006/2007: 9) like the stories of Sveta when people sink back into the wildness when work is gone and alcohol abuse has arisen. "Wilderness" is constantly threatening "civilisation" and in recent decades has been taking back its space. Due to the economic crisis after the collapse of the Soviet Union, mines and settlements have been closed, out-migration increased and in many regions the former 
"civilised" space has been decreasing (cf. Vitebsky 2002: 184). One way of recreating "civilisation" was the constant import of industrially manufactured goods, construction material and non-regional food that helped people to feel they are in a "civilised" environment. This surplus was guaranteed in the Soviet era mainly by state trading structures providing shops in remote villages. With the collapse of the Soviet economy, the private traders replaced the state shops. Metaphorically, private traders are central in the struggle against the "wilderness" helping to demonstrate peoples' kul'turnost' providing fashionable clothes, chocolate, bananas, watermelons and so forth.

Entrepreneurship in Siberia is often discussed in the context of indigenous activities in a post-socialist period. Dmitriev (2004: 154-155) distinguishes four different kinds of indigenous entrepreneurship - traditional forms of land use (hunting, reindeer herding, fishing), revival of traditional handicrafts, developing local services and infrastructure, and tourism. The particularity of indigenous business is that the actors tend to start and run their activities in their home communities and are often female (Dmitriev 2004: 154). In the wider context of modern Russia (and former socialist countries in general), entrepreneurship is in academic literature often discussed as a sphere linked with criminality and the shadow economy (Humphrey 2002; Holzlehner 2007; Kaneff 2002; Konstantinov 1997). What has been given less attention is the non-indigenous small scale entrepreneurship. The "small scale" means here everything but geography. Discussing the barter in Siberia, Nikolai Ssorin-Chaikov demonstrates the wide range of trading networks reaching from Central Siberia to Central Asia (Ssorin-Chaikov 2000).

Trading entrepreneurs here follow the general pattern and are nothing exceptional. People in Siberia move a lot and cross huge distances (e.g., Argunova-Low 2007), the main difference between local indigenous people and entrepreneurs according to my observations is that entrepreneurs totally ignore the existence of any kind of life outside of the villages. I was surprised when I found out that most entrepreneurs have very little knowledge of how people live in the tundra. Even Sveta, after living in Iurung Khaia for a long time, had never been in the tundra. The traders' world of Siberia is a small world, staying mostly within the limits of the village and centering around the shop, hotel, home and the village administration. Traders were very similar to incomers working in local administration who spent every holiday in the "materik", in places that were "civilised" and "cultural" (Ventsel 2005: 127). In this sense, entrepreneurs lived literally in the "civic islands" mentioned by Anderson (1996: 111-112), places that were "actually governed" (Fondahl 1995: 4) and avoided consciously the "wilderness". Like Alaskan Inuits, the incoming population in Siberia tends to shun any communication between the tundra 
and villages (cf. Bodenhorn 1993) only contrary to the Inuits, the Siberian incomer population tend to ignore the space outside of the village. For entrepreneurs, villages are not only "spaces for economic practice" (Smith 2002) but also "inside" places that make sense and where they feel emotional and social links to the their environment (Hirsch 1996). Tundra and the life in it embodied for entrepreneurs an "outside" place and had little to do with their everyday life, whereas shops, streets, airports and so forth as a meaningful context formed the everyday, un-reflexive form of experience (see Bourdieu 1977). On the other hand, traders can be part of the society because they have proved they are worthy of respect. Some of them, like my informants, consider the village their home and are unsure of leaving it even when they have the possibility.

The movement of entrepreneurs and goods in the context of civilised islands has more nuances than just crossing distances between different settlements. Piers Vitebsky argues that after the collapse of the Soviet Union and the disappearance of subsidised transport, the distances in Siberia are a burden (Vitebsky \& Alekseyev 2000). In the Siberian Arctic, airports and air routes form a network of civilisation. However, peoples' attitude to this burden is very stoic. Flying around in Siberia involves a huge waste of time. Not only are distances large and flying time between the settlements takes hours but there is additional time to invest in the whole process of travelling. To catch a flight, one has to be at the airport several hours before the plane takes off. Very often flights are postponed and one can get stuck in a strange place not only for hours but days (as has happened to me some times). All Siberian airports are full of people with huge bags waiting for their flights. I can easily imagine Sveta and her son sitting in an airport on a huge travel bag surrounded by a dozen of other bags waiting hours for a connecting flight. Sveta would sit on the bag, even sleep on it and stand up only to go and buy hot tea at the canteen. This deep stoicism of Siberians is in sharp contrast with the pictures of hysteric Western Europeans getting stuck in airports during bad weather in December 2010 or due to the volcano ash panic earlier that year.

Time consuming travelling has always been part of living on the eastern side of the Ural mountains as long as people can remember. As already mentioned, travelling in Siberia is a process taking not only hours but sometimes days. People know it and this belongs to living on this land. Entrepreneurs, as other inhabitants of Siberia, know that spending a long time on the road is the only possibility to reach other villages or going to the town. Coping with this kind of distance (to paraphrase Vitebsky \& Alekseyev 2000) is their lived experience and social relationship to the land, discussed in another context by so many scholars (e.g., Bourdieu 1977; Hirsch 1996). In many aspects, viewing 
inconvenience and problems as part of the process of movement mirrors the frontier ethos in Siberia which expects that a man or a woman has to be above hardships and only this way demonstrate that they are able (and worthy) to live in this hard country. This attitude is fundamental for the regional identity of Siberians or sibiriak and is something that distinguishes Siberians from people of the materik. Both in the past and in modern times sibiriak means consolidation of a regional identity around aspects of life that should be a disadvantage but are turned into a matter of local pride (Czaplicka 1916; Antipin 2011).

Moreover, the sibiriaki have only one chance of being in the "civilisation", on the side of kul'tura and this option is to bear the long distance travelling and inconvenience linked with it. Entrepreneurs not only brought in "civilisation" by importing goods from the materik, but also moved inside this network that connected them with "civilisation", i.e. only space that matters. Outside of the villages and their airports exists for them the "wilderness" which for incomers is equal to the empty and non-inhabited space they have no relationship to. From a trader's point of view, their living environment is a "civilised society at the edge of the polity" (Brightman et al. 2006/2007: 9) which means that they are moving in the network that keeps the "civilisation" together in an otherwise untamed frontier. When mapping the movement of traders and their goods and money then it is obvious that they limit their activities within the network of kul'tura avoiding too close contact with the space outside of it. Importing goods is, among others, the trader's contribution to the eternal process of establishing and supporting a fragile frontier against the "wilderness". I would not claim that the Siberian traders have a deep ideological mission to keep civilisation alive in the frontier's everlasting struggles, their main motivation is to make money. However, in many settlements their shops and backrooms are the only source of products that symbolise kul'tura for both indigenous people and incomers. Selling these goods, traders use the money to create their own civilised space as well - to raise their living standards or build houses such as Sveta. The only way of having these goods is the movement within the huge network that is filled with symbols that in Siberia mark the expansion of civilisation and the siege against the wilderness - airports, polar aviation and trucks. On the other hand, moving these goods is hard work, that one has to manage as every other sibiriak in mastering the hardships of life. In their ethos and world view, traders typify incomer ignorance of the "wilderness" by living in the "network of civilisation" with the sibiriak ethos of hard work and tough personality. In short, globalisation that includes the spread of international fashion and goods should cause deterritorialisation (see Appadurai 2002: 54) but the Siberian case demonstrates that under certain circumstances the reverse process of fostered territorialisation occurs. 


\section{CONCLUSION}

In my article I discuss the movement of traders and their goods and money in the context of a frontier. Viewing Siberia as a (resource) frontier has long been a tradition and in popular perception Siberia still is a space where "civilisation" and "wilderness" are in constant conflict. The world of the traders is not much different from the environment of other people living in Siberia - they have to cope with huge distances, a harsh climate and inconvenience due to the lack of civilisation and progress. My main arguments in this article are that the general interpretation of space and movement in Siberia is specific for a frontier and this is the reason why people are willing to accept such a life in this environment. On the one hand, travelling long distances has always been part of living in that region. "Coping with distance" (Vitebsky \& Alekseyev 2000) is an expression of the frontier ethos that is embodied in the identity of sibiriak. Sibiriaki are tough frontier people that have to fight to survive. Climate, living conditions and distances are part of the Siberian "lived experience" (Bourdieu 1977) that distinguished local people from inhabitants of European Russia, and makes them proud of their achievement. On the other hand, newcomers do not live in a "wild world". In their activities and travels they try to avoid "wilderness" as much as possible. Traders combine both views. Travelling thousands of kilometres does not mean to them travelling around in a wild and uncivilised country. On the contrary, the movement of entrepreneurs and their goods stays inside the "network of civilisation". Not only does private trade contribute to the survival of the civilisation in a frontier, it takes place in a space that local people interpret as fully "civilised" - settlements, airports, airplanes, trucks. The hardships, linked to travelling, are seen as an organic part of the Siberian lifestyle and nothing unusual. Enduring long waits, long journeys and moving heavy luggage is a sign that one can cope with the harsh environment and one has the right to be there.

By following traders we also see how space is socially and culturally constructed and supported by economic activities. To understand the specific Siberian point of view interpreting space and movement in the region one has to take into account the historical context that sees Siberia as an unfinished frontier. 


\section{NOTES}

1 This research was supported by the European Union through the European Regional Development Fund (Centre of Excellence in Cultural Theory CECT), University of Tartu and Max Planck Institute for Social Anthropology in Halle (Saale), Germany.

2 The content of the expression kommersant is an ambivalent one. It is linked to the semi-legal activities of the traders which is caused by the non-regulated market economy in Russia. Trade in Russia includes cooperation with criminal groups, corruption and the shadow economy. On the other hand, traveling and local kommersanty are in many Siberian villages the only access to imported goods. The ambivalence of private entrepreneurship is very well discussed in several publications (e.g., Humphrey 1991; Mandel \& Humphrey 2002)

${ }^{3}$ One reason for the barter is the ever changing value and mistrust of the rouble. Anderson (2000a: 343) argues that in the mid-1990s 'financial crises ... disqualified the rouble from the role as instrument of social integration'. Another reason is that via barter traders can manipulate prices more efficiently as I have shown elsewhere (Ventsel 2005: Chapter 3).

${ }^{4}$ The most common way of sending parcels to the district was to ask people at the airport to take parcels with them. It always depended on whether one was able to find someone who was generous enough to take more weight with them.

${ }^{5}$ Social construction of space is especially well demonstrated in the drawing of maps. The research shows that cartography is not "objective" but rather "subjective", one can state that the map is how the drawer's eye sees (Gow 1996; Tagirova 2007; Petto 2006; Skocz 2006).

\section{REFERENCES}

Anderson, David G. 1996. Bringing Civil Society to an Uncivilised Place: Citizenship regimes in Russian's Arctic Frontier. In: C. M. Hann \& E. Dunn (eds.) Civil Society. Challenging Western Modes. London, New York: Routledge, pp. 99-120.

Anderson, David G. 2000a. Surrogate Currencies and the 'Wild Market' in Central Siberia. In: P. Seabright (ed.) The Vanishing Rouble: Barter Networks and Nonmonetary Transactions in Post-Soviet Societies. Cambridge, New York: Cambridge University Press, pp. 318-344.

Anderson, David G. 2000b. Identity and Ecology in Arctic Siberia: The Number One Reindeer Brigade. Oxford: Oxford University Press.

Antipin, Vladimir 2011. Grazdanin Sibiri. Pochemu russkie za uralom ne khotiat byt' russkimi. Ruskii Reporter, 22.02.2011, http://rusrep.ru/article/2011/02/22/sibir/ - last accessed 5 Dec 2011.

Appadurai, Arjun 2002. Disjuncture and Difference in the Global Cultural Economy. In: J. X. Inda \& R. Rosaldo (eds.) The Anthropology of Globalization. Malden, MA: Blackwell, pp. 46-63.

Argunova-Low, Tatiana 2006/2007. Frontier: Reflections from the Other Side. Cambridge Anthropology, Vol. 26, No. 2, pp. 47-56. 
Argunova-Low, Tatiana 2007. Close Relatives and Outsiders: Village People in the City of Yakutsk, Siberia. Arctic Anthropology, Vol. 44, No. 1, pp. 51-61.

Bassin, Mark 1991. Inventing Siberia: Visions of the Russian East in the Nineteenth Century. The American Historical Review, Vol. 96, No. 3, pp. 763-794.

Basso, Keith H. 1984. "Stalking with Stories": Names, Places and Moral Narratives among Western Apache. In: E. Brenner (ed.) Text, Play and Stay. Waveland: Prospect Heights, pp. 19-55.

Billington, Ray Allen 1956. The Far Western Frontier. New York, Evanston: Harper \& Row, Inc.

Bodenhorn, Barbara 1993. Gendered Spaces, Public Places: Public and Private Revisited on the North Slope of Alaska. In: B. Bender (ed.) Landscape. Politics and Perspectives. Providence, Oxford: Berg, pp. 169-203.

Bothe, Michael \& Kurzidem, Thomas \& Schmidt, Christian 1993. Amazonia and Siberia: Legal Aspects of the Preservation of Environment in the Last Open Spaces. London: Graham \& Trotman.

Bourdieu, Pierre 1977. Outline of a Theory of Practice. Cambridge: Cambridge University Press.

Brandtstädter, Susanne 2001. Re-defining Place in Southern Fujian: Overseas Mansions and Ancestral Halls Re-appropriate Local from State. Halle/Saale: Max Planck Institute for Social Anthropology.

Brightman, Marc \& Grotti, Vanessa Elisa \& Ulturgasheva, Olga 2006/2007. Introduction: Rethinking the 'Frontier' in Amazonia and Siberia: Extractive Economies, Indigenous Politics and Social Transformations. Cambridge Anthropology, Vol. 26, No. 2, pp. 1-13.

Brightman, Marc \& Grotti, Vanessa Elisa \& Ulturgasheva, Olga 2010. Personhood and "Frontier" in contemporary Amazonia and Siberia. Laboratorium, Vol. 2, No. 3, pp. 348-365.

Buchan, Bruce \& Heath, Mary 2006. Savagery and Civilization: From Terra Nullius to the 'Tide of History'. Ethnicities, Vol. 6, No. 1, pp. 5-26.

Burbank, Jane \& Hagen, Marc von 2007. Coming into Territory: Uncertainty and Empire. In: J. Burbank \& M. v. Hagen \& A. Remnev (eds.) Russian Empire. Space, People, Power, 1700-1930. Bloomington and Indianapolis: Indiana University Press, pp. 1-32.

Cañas Bottos, Lorenzo 2008. Old Colony Mennonites in Argentina and Bolivia. Nation Making, Religious Conflict and Imagination of the Future. Leiden, Boston: Brill.

Certeau, Michel de 1988. The Practice of Everyday Life. Berkley, Los Angeles, London: University of California Press.

Collins, David N. 2004. Sexual Imbalance in Frontier Communities: Siberia and New France to 1760. Sibirica, Vol. 4, No. 2, pp. 162-185.

Croll, Elisabeth \& Parkin, David (eds.) 1992. Bush Base: Forest Farm. Culture, Environment and Development. London: Routledge.

Czaplicka, Maria Antonina 1916. The Siberian Colonist or Sibiriak. In: S. Wayne (ed.) The Soul of Russia. London: Macmillan, 123-132.

Dedering, Tilman 2002. Globalization, Global History, and Africa. Journal of Asian and African Studies, Vol. 37, No. 3-5, pp. 271-285. 
Dick, Everett 1965. Vanguards of the Frontier. A Social History of the Northern Plains and Rocky Mountains from the Fur Traders to the Sod Busters. Lincoln, London: University of Nebraska Press.

Dmitriev, Vladimir 2004. Small-numbered Peoples and Small Business: Steps Towards Finding Common Ground. Sibirica, Vol. 4, No. 2, pp. 132-149.

Fondahl, Gail A. 1995. Legacies of Territorial Reorganization for Indigenous Land Claims in Northern Russia. Polar Geography, Vol. 19, No. 1, pp. 1-21.

Forsyth, James 1992. A History of the Peoples of Siberia. Russia's North Asian Colony 1581-1990. Cambridge: Cambridge University Press.

Foucault, Michel 1980. Power / Knowledge. Selected Interviews and Other Writings 1972 1977. Bury St Edmunds: The Harvester Press.

Gentes, Andrew A. 2003. 'Licentious Girls' and Frontier Domesticators: Women and Siberian Exile from the Late 16th to the Early 19th Centuries. Sibirica, Vol. 3, No. 1 , pp. 3-20.

Gerasimov, Ilya \& Kusber, Jan \& Semyonov, Alexander (eds.) 2009. Empire Speaks Out: Languages of Rationalization and Self-Description in the Russian Empire. Leiden: Brill.

Ginsburg, Faye \& Meyers, Fred 2006. A History of Aboriginal Futures. Critique of Anthropology, Vol. 26, No. 1, pp. 27-45.

Gow, Peter 1996. Land, People, and Paper in Western Amazonia. In: E. Hirsch \& M. O'Hanlon (eds.) The Anthropology of Landscape. Perspectives on Place and Space. Oxford: Clarendon Press, pp. 43-62.

Gracheva, Galina N. 1980. Taimyrskii poselok Ust-Avam (preobrazovaniia v khoziaistve i etnicheskiie protsessy). In: S. M. Abramzon \& I. V.Vdovin \& I. V. Tsustov (eds.) Etnograficheskiie aspekty izucheniia sovremennosti. Leningrad: Nauka, pp. 136152.

Gray, John N. 2000. At Home in the Hills. Sense of Place in the Scottish Borders. New York, Oxford: Berghahn Books.

Harvey, David 1990. The Condition of Postmodernity. Cambridge MA: Blackwell Publishing.

Hill, Fiona \& Gaddy, Clifford 2003. The Siberian Curse. How Communist Planners left Russia out in the Cold. Washington, D.C.: Brookings Institution Press.

Hine, Robert V. 1984. The American West. An Interpretive History. United States of America: Harper Collins.

Hirsch, Eric 1996. Introduction. Landscape: Between Place and Space. In: E. Hirsch \& M. O'Hanlon (eds.) The Anthropology of Landscape. Perspectives on Place and Space. Oxford: Clarendon Press.

Holzlehner, Tobias 2007. "The Harder the Rain, the Tighter the Roof": Evolution of Organized Crime Networks in the Russian Far East. Sibirica, Vol. 6, No. 2, pp. $51-86$.

Humphrey, Caroline 1991. 'Icebergs', Barter, and the Mafia in Provincial Russia. Anthropology Today, Vol. 7, No. 2, pp. 8-13.

Humphrey, Caroline 2002. The Unmaking of Soviet Life. Everyday Economies after Socialism. Ithaca, London: Cornell University Press.

Humphrey, Caroline \& Hugh-Jones, Stephen (eds.) 1997. Barter, Exchange and Value. An Anthropological Approach. Cambridge, New York, Port Chester, Melbourne, Sydney: Cambridge University Press. 
Ingold, Tim 2000. The Perception of the Environment. Essays on Livelihood, Dwelling and Skill. London, New York: Routledge.

Kaneff, Deema 2002. The Shame and Pride of Market Activity: Morality, Identity and Trading in Postsocialist Rural Bulgaria. In: C. Humphrey \& R. Mandel (eds.) Markets and Moralities: Ethnographies of Postsocialism. Oxford, New York: Berg, pp. 33-52.

Kennedy, Dorothy 2002. Culture and Politics in the Aboriginal Landscape: Reflections on the Identification of Culturally Significant Places in Western North America. In: M. Saltman (ed.) Land and Territoriality. Oxford, New York: Berg, pp. 9-36.

Kolodny, Annette 1984. The Land Before Her. Fantasy and Experience of the American Frontiers, 1630-1860. Chapel Hill, London: The University of North Carolina Press.

Konstantinov, Yulian 1997. 'Memory of Lenin' Ltd. Reindeer-Herding Brigades on the Kola Peninsula. Anthropology Today, Vol.13, No.3, pp. 14-19.

Kotkin, Stephen \& Wolff, David (eds.) 1995. Rediscovering Russia in Asia. Siberia and the Russian Far East. Armonk, New York, London, England: M.E.Sharpe.

Kozlar, Walter 1955. Russia and her Colonies. New York: Frederick A. Praeger.

Lefebre, Henri 1991. The Production of Space. Oxford: Blackwell Publishers.

Linde-Laursen, Anders \& Nilsson, Jan Olof (eds.) 1995. Nordic Landscopes. Cultural Studies of Place. Stockholm, Copenhagen: Nord.

Mandel, Ruth Ellen \& Humphrey, Caroline (eds.) 2002. Markets and Moralities: Ethnographies of Postsocialism. Oxford, New York: Berg.

Mote, Victor L. 1998. Siberia. Worlds Apart. Boulder, Oxford: Westview Press.

Mowat, Farley 1970. The Siberians. London: Heinemann.

Obrutšev [Obruchev], Sergei V. 1957. Tundmatutel radadel. Reisid põhja-aladele aastail 1917-1930. [Into Unknown Regions.] Tallinn: Eesti Riiklik Kirjastus.

Pelto, Pertti J. \& Müller-Wille, Ludger 1987. Snowmobiles. Technological Revolution in the Arctic. In: H. R. Bernhard \& P. J. Pelto (eds.) Technology and Social Change. Second Edition. Prospect Heights, Illinois: Waveland Press, Inc, pp. 208-241.

Petto, Christine M. 2006. Enlightenment Geography and Local Mapping Initiatives: From Office to the Field, 1700-1815. In: G. Backhaus \& J. Murungi (eds.) Ecoscapes. Geographical Patternings of Relations. Lanhan, Boulder, New York, Toronto, Oxford: Lexington Books, pp. 97-116.

Skocz, Dennis E. 2006. Ecology, Technology, and Wilderness Management: A Clash of Eco-Spatial Paradigms. In: G. Backhaus \& J. Murungi (eds.) Ecoscapes. Geographical Patternings of Relations. Lanhan, Boulder, New York, Toronto, Oxford: Lexington Books, pp. 115-138.

Slavin, Samuil V. 1961. Promyshlennoe i transportnoe osvoenie Severa SSSR. Moskva: Ekonomizdat.

Smith, Adrian 2002. Culture/Economy and Spaces of Economic Practice: Positioning households in Post-Communism. Transactions of the Institute of British Geographers. New Series, Vol. 27, No. 2, pp. 232-250.

Ssorin-Chaikov, Nikolai 2000. Bear Skins and Macaroni: The Social Life of Things at the Margins of a Siberian State Collective. In: P. Seabright (ed.) The Vanishing Rouble: Barter Networks and Non-Monetary Transactions in Post-Soviet Societies. Cambridge: Cambridge University Press, pp. 345-361. 
Stammler, Florian 2005. Reindeer Nomads Meet the Market: Culture, Property and Globalisation at the End of the Land. Halle Studies in the Anthropology of Eurasia 6. Münster: LIT Verlag.

Stammler, Florian \& Ventsel, Aimar 2003. Between Neo-Liberalism and Dirigisme: Approaches to Reindeer Herding in Yamal and Sakha. In: C. M. Hann \& 'Property Relations' Group (eds.) The Postsocialist Agrarian Question. Property Relations and the Rural Condition. Halle Studies in the Anthropology of Eurasia 1. Münster: LIT Verlag, pp. 321-363.

Stephan, John J. 1994. The Russian Far East. A History. Stanford, California: Stanford University Press.

Sunderland, Willard 2007. Imperial Space: Territorial Thought and Practice in the Eighteenth Century. In: J. Burbank \& M. v. Hagen \& A. Remnev (eds.) Russian Empire: Space, People, Power, 1700-1930. Bloomington, Indianapolis: Indiana University Press, pp. 33-66.

Tagirova, Nailya 2007. Mapping the Empire's Economic regions from the Nineteenth to the Early Twentieth Century. In: J. Burbank \& M. v. Hagen \& A. Remnev (eds.) Russian Empire. Space, People, Power, 1700-1930. Bloomington, Indianapolis: Indiana University Press, pp. 125-138.

Tilly, Charles 1975. Reflections on the history of European state-making. In: C. Tilly (ed.) The Formation of National States in Western Europe. Princeton: Princeton University Press, pp. 3-83.

Ventsel, Aimar 2005. Reindeer, Rodina and Reciprocity: Kinship and Property Relations in a Siberian Village. Halle Studies in the Anthropology of Eurasia 7. Berlin: LIT Verlag.

Vitebsky, Piers \& Alekseyev, Anatoly 2000. Coping with Distance: Social, Economic and Environmental Change in the Sakha Republic (Yakutia), Northeast Siberia. Report on Expedition funded by the Gilchrist Educational Trust in Association with the Royal Geographical Society, 1999. Cambridge: University of Cambridge, Scott Polar Institute.

Vitebsky, Piers 2002. Withdrawing from the Land. Social and Spiritual Crisis in the Indigenous Russian Arctic. In: C. M. Hann (ed.) Postsocialism. Ideals, Ideologies and Practices in Eurasia. London: Routledge, pp. 180-195.

Vitebsky, Piers \& Wolfe, Sally 2001. The Separation of the Sexes Among Siberian Reindeer Herders. In: A. M. Low \& S. Tremayne (eds.) Sacred Custodians of the Earth? Women, Spirituality, and the Environment. New York: Berghahn Books, pp. 81-94.

Watts, Michael J. 1992. Space for Everything. Cultural Anthropology, Vol. 7, No. 1, pp. 115-129.

Weiner, James 2002. Between a Rock and a Non-Place: Towards a Contemporary Anthropology of Place. Reviews in Anthropology, Vol. 31, No. 1, pp. 21-27.

Wilkie, Laurie A. 2010. The Lost Boys of Zeta Psi. A Historical Archaeology of Masculinity at a University Fraternity. Berkley, Los Angeles, London: University of California Press.

Wolf, Eric 1990. Europe and the People Without History. Berkley, Los Angeles, London: University of California Press.

Ziker, John P. 2002. Peoples of the Tundra. Northern Siberians in the Post-Communist Transition. Prospect Heights, Illinois: Waveland Press, Inc. 